individual clinical problems. Nonetheless they do form collectively a useful physiological tool for defining more sharply the gross nature of the chemical relationships which occur in the body under different conditions of nutrition.

\title{
REFERENCES
}

Bradley, J. E. S., Davidsson, D., MacIntyre, I. \& Rapoport, A. (1956). Biochem. F. 62, 33 P.

Brodie, B. B., Axelrod, J., Soberman, R. \& Levy, B. B. (1949). F. biol. Chem. 179, 25.

Brožek, J. (1952). Fed. Proc. Ix, 784.

Hevesy, G. \& Hofer, E. (1934). Nature, Lond, r34, 879.

Keys, A. \& Brožek, J. (1953). Physiol. Rev. 33, 245.

Keys, A., Brožek, J., Henschel, A., Mickelsen, O. \& Taylor, H. L. (1950). The Biology of Human Starvation. Minneapolis: University of Minnesota Press.

Lesser, G. T., Blumberg, A. G. \& Steele, J. M. (1952). Amer. F. Physiol. 169, 545.

McMurrey, J. D., Boling, E. A., Davis, J. M., Parker, V. H., Magnus, I. C., Ball, M. R. \& Moore, F. D. (1958). Metabolism, 7, 661.

Moulton, C. R. (1923). F. biol. Chem. 57, 79.

Murray, J. A. (1922). F. agric. Sci. 12, 103.

Pace, N. \& Rathbun, E. N. (1945). F. biol. Chem. 158, 685.

Painter, E. E. (1940). Amer, F. Physiol. 129, 744.

Prentice, T. C., Siri, W., Berlin, N. I., Hyde, G. M., Parsons, R. J., Joiner, E. E. \& I awrence, J. H. (1952). F. clin. Invest. 31, $4 \mathrm{I} 2$.

Ralls, J. O. (1943). F. biol. Chem. r51, 529.

Schloerb, P. R., Friis-Hansen, B. J., Edelman, I. S., Solomon, A. K. \& Moore, F. D. (1950). F. clin. Invest. 29, 1296.

Soberman, R., Brodie, B. B., Levy, B. B., Axelrod, J., Hollander, V. \& Steele, J. M. (1949). F. biol. Chem. I79, $3 \mathrm{I}$.

Solomon, A. K., Edelman, I. S. \& Soloway, S. (1950). F. clin. Invest. 29, I3 II.

Steele, J. M., Berger, E. Y., Dunning, M. F. \& Brodie, B. B. (1950). Amer. F. Physiol. 162, 3 I 3.

\section{The assessment of marginal protein malnutrition}

\section{By J. C. WATERLow, * M.R.C. Tropical Metabolism Research Unit, University of the West Indies, Famaica}

Everyone at this meeting knows the importance of protein-calorie malnutrition as a world problem. In the last few years the focus of interest has been shifting from the severe to the milder cases. In the advanced stages mortality is still high, and there are many aspects of the syndrome that are not understood. Nevertheless, in relation to practical public health the problem of marginal malnutrition is the more urgent. Without some reasonably accurate means of assessing nutritional status with respect to protein it is impossible to plan preventive measures in an accurate or economical way. An enormous effort has been put into supplementary feeding programmes in different parts of the world, but because methods of evaluation are so crude we do not really know how effective these programmes have been.

To assess marginal protein malnutrition we must know what are the characteristics of the protein-depleted body, and for this purpose it is logical to work back from severe to mild changes. It may be useful as a background, therefore, to begin by summarizing some of the relevant findings in advanced cases (see Waterlow, Cravioto \& Stephen, r960).

*Present address: clo Department of Chemical Pathology, St Mary's Hospital, London, W.2. 
The protein-depleted infant is, of course, too small--perhaps half the normal weight for its age. It is also different from normal infants in gross composition, since the proportions of water and fat, and hence of protein, are abnormal. More important, however, than these changes in amount or concentration is the fact that the distribution of protein in the body is altered. This is found at all levels of organization-that of the organ, the tissue and the cell.

Both in animals and man, measurement of the weight or protein content of organs shows that in malnutrition some are reduced in size more than others. The extremes are brain, which is maintained at almost the normal weight, and muscle mass, which may be reduced to $30 \%$ of normal (Addis, Poo \& Lew, 1936; KerpelFronius \& Frank, r 949). Proportionately, therefore, the reduction in muscle mass may be much greater than in body-weight as a whole.

At the tissue level it is convenient, following Darrow \& Hellerstein (1958), to make a broad distinction between mobile proteins, chiefly those of the parenchymatous organs, and fixed proteins, chiefly those of the supporting structures and vascular system. The fixed proteins are less reduced than the mobile; collagen is an excellent example. In the malnourished muscle the proportion of collagen is greatly increased (Mendes \& Waterlow, 1958), so that the microscopic picture may suggest a fibrosis (Montgomery, 1962). Finally, at the level of the cell, the overall loss of cytoplasmic protein is shown by a reduction in the amount in relation to DNA. The study of intracellular enzymes, if it has shown nothing else, has made it clear that this loss of protein is not uniform, some cell proteins being preserved better than others (Knox, Auerbach \& Lin, r956; Waterlow, 1959).

All these changes at various Jevels of organization can be summarized in one phrase: alterations in pattern. The first principle to be emphasized is that the altered pattern of protein distribution is not static; it must be continually changing according to the severity and duration of protein deficiency and the level of calorie intake. The influence of these factors is well shown by some experimental results of Widdowson \& McCance (1956) (Table I).

Table I. Nitrogen content of liver and body in undernourished and starved rats expressed as a percentage of that in controls

$\begin{array}{cccc}\text { Body-weight } & \mathrm{N} \text { in liver } & \begin{array}{c}\mathrm{N} \text { in rest } \\ \text { of body }\end{array} \\ \text { Rats acutely starved } & 73 & 6 \mathrm{r} & 88 \\ \text { Rats chronically undernourished } & 70 & 68 & 72 \\ \text { From Widdowson \& McCance (I956) } & \end{array}$

When we come to functional changes it is necessary to distinguish between pathological breakdowns and physiological adjustments. Under the first heading can probably be classed abnormalities of liver function, increases in serum enzymes such as transaminases (Edozien, I96r; McLean, r 962), and perhaps the block in metabolism of some amino acids discovered by Dean and his co-workers (Dean, 196r; Whitehead \& Arnstein, 196r). Important though these changes are, it is remarkable how well overall protein metabolism is preserved even in very 
severe protein malnutrition. In our experience, absorption of nitrogen is little impaired, nitrogen retention, and presumably utilization, proceeds at a high rate, and the partition of urinary nitrogen is normal (Waterlow \& Wills, 1960; Waterlow, I 963 ). Nevertheless, in a body whose pattern is distorted in the way I have described, these successful overall responses must depend on adjustments in the rates and equilibria of the underlying processes. Therefore I suggest as a second principle that in the study of early protein malnutrition it will not be fruitful to look for specific qualitative changes, as implied in the phrase 'diagnostic test'; rather we have to concentrate on the measurement of quantitative deviations. This seems obvious, but, as I have emphasized, the disturbance of pattern is complicated, and it is not a simple matter to decide which measurements are significant. It seems likely that the processes of protein breakdown and renewal in the body are regulated by a homoeostatic mechanism of which we know almost nothing. If that is so, the first task is to distinguish between those elements or functions which are allowed to vary, and those which are held constant at almost any price. I shall attempt to illustrate these general points with practical examples.

\section{Anthropometric and clinical measurements}

Reduction of body-weight in relation to age or height is still the most widely used index of malnutrition. Stunting in height is perhaps evidence of a long-continued process, whereas a weight deficit can, of course, be established in a quite short time. Therefore both measurements are desirable. The question of so-called 'normal' standards has to be considered for each population, but need not be dealt with here. One difficulty which is often neglected is the extremely large variability from one day to the next of the body-weight of young children when measured under field conditions, however careful the technique of weighing. Much attention ought to be given to this variation from a statistical point of view in the planning of surveys and feeding trials.

Muscle is the most important protein reservoir of the body. In advanced proteincalorie malnutrition the reduction in muscle mass is greater than the reduction in body-weight, so that the weight deficit seriously underestimates the extent of depletion (Standard, Wills \& Waterlow, I959). Muscle mass should therefore provide a more sensitive index than crude body-weight. In field surveys a rough estimate can be obtained by measurement of $\operatorname{limb}$ circumference corrected for skinfold thickness. In order to determine whether the figure so obtained is really a measure of muscle mass, some independent estimate is needed. We found that in babies recovering from malnutrition there was a significant correlation between increase in muscle thickness and increase in creatinine output (Standard et al. 1959). A very high correlation between 'muscularity' measured in this way and creatinine output was found also by Arroyave \& Wilson (I96I). It is interesting also that in a survey of preschool children and schoolchildren in Jamaica, most of whom were underweight, measurements of skinfold thickness and muscle thickness indicated that both components-fat and muscle-were uniformly decreased. This fits in with the results of dietary surveys in Jamaica and with analyses of Jamaican meal patterns in 
Professor B. S. Platt's Human Nutrition Research Unit at Mill Hill. These show that the diet is reasonably well balanced, but inadequate in total amount.

There are many minor clinical signs that are often used as indices of malnutrition apart from those produced by specific vitamin deficiencies. Among the commonest are changes in the colour and texture of the hair and in the skin. In our survey in Jamaica no correlation was found between the incidence of these changes and the extent of deficit in weight or height. It has long been recognized that in established kwashiorkor these changes bear no relation whatever to the severity of general malnutrition (Waterlow, 1948). It seems possible that, as suggested some years ago by Bigwood (I954), these lesions of keratinized structures might result from a preponderant deficiency of sulphur amino acids which are often limiting in human diets.

\section{Biochemical measurements}

Urinary urea. It has often been suggested that urea output might be used as an index of protein nutrition. The studies of Luyken \& Luyken-Koning (1960) in Surinam, of Platt (1954) in Africa and of Arroyave (1962) in Guatemala show that urea nitrogen, expressed as a proportion of total urinary $\mathrm{N}$, was low in groups whose dietary intake was inadequate. There is no evidence that this was the result of any failure in the mechanism of urea formation (Waterlow, 1963). In a series of infants in Jamaica, some of whom were very severely malnourished, others recovering, the proportion of urea $N$ in the urine bore exactly the same relation to the total urinary $N$ as was found by Phansalkar \& Patwardhan (1954) in normal Indian adults, and by Folin $(1905 a, b)$ in American adults. The ratio of urea $\mathrm{N}$ to total $\mathrm{N}$ (which is conveniently called the urea index) therefore reflects the recent $\mathrm{N}$ intake and not the physiological or nutritional state of the subject. 'This distinction is important. However, a continued low intake must obviously lead to malnutrition, so that in poor countries, where the diet is often monotonously uniform, the urea index may give valuable indirect evidence of nutritional status.

In our work on malnourished children we have not been able to confirm the observation of Platt \& Heard (I958) that there is an increase in urinary ammonia. On the contrary, the absolute ammonia output was, if anything, reduced at the time when the babies were most malnourished (Table 2). The residual $N$ (i.e. the sum of the $\mathrm{N}$ of the remaining constituents other than that of urea and $\mathrm{NH}_{3}$ ) showed little variation (Table 2). This finding is in some conflict with the results of Edozien \& Phillips (1961) in Nigeria and of Dean (I96I) in Uganda, who have observed a large increase in output of amino acids and amino acid metabolites. It may be that there is a regional difference, or that we have simply missed this phenomenon. In any event, it is probably a breakdown effect found in severely ill patients and will not help much in the assessment of marginal malnutrition.

Urinary creatinine. The measurement of muscle mass is one step nearer our objective than the measurement of crude body-weight. I believe that the classical index-the $24 \mathrm{~h}$ creatinine output-is a most valuable tool for this purpose. In malnourished infants in our Unit the output rose by a factor of 2 or 3 in the course 
Table 2. Partition of urinary nitrogen in malnourished infants at different stages after admission to hospital

Days from
admission
$0-2$
$6-10$
$16-20$
$26-35$
$45+$

Body-weight
(\% of standard)
57
57
57
62
76

Absolut
Total N
ro9
128
248
243
428

output
$\mathrm{NH}$
$\mathrm{I9}$
23
26
26
32

$\mathrm{g} / \mathrm{kg}$ day)
Residual $N$
22
34
36
24
34

Urea N
(\% of total N)
58
$5 \mathrm{r}$
73
78
83

of treatment. In Guatemala, Arroyave \& Wilson ( 1961 ) found significant differences in creatinine output in groups of children of different economic status.

However, the interpretation that creatinine output measures muscle mass should, if possible, be verified independently. In healthy adults it has been shown to correlate well with lean body mass, red-cell mass and total oxygen uptake (Miller \& Blyth, I952), but such relationships have not yet been established in malnourished children. There are also practical difficulties about this test. First, there are significant fluctuations in output from day to day, even on diets that do not contain exogenous creatine (Bleiler \& Schedl, 1962). The measurement is therefore best suited for group or serial studies. Secondly, a timed collection of urine is necessary and, although it seems that the rate of creatinine excretion is constant throughout the $24 \mathrm{~h}$, so that a $3 \mathrm{~h}$ collection period, as suggested by Arroyave \& Wilson (196r), should be satisfactory, the shorter the period the greater the error.

In spite of these disadvantages, creatinine output seems a most promising survey tool, particularly if measurements of urea and total $\mathrm{N}$ are made at the same time. I see no advantage in expressing the results as the ratio of urea to creatinine, because this combines in one figure two separate variables-intake and nutritional state. These may work in opposite directions: a low intake reduces the ratio, but a poor nutritional state raises it, since creatinine output is reduced.

Plasma albumin. The plasma proteins represent another protein mass that can be measured by existing methods. Many surveys have shown that total protein and albumin concentrations in plasma are little, if at all, reduced in marginal malnutrition. It seems that the low levels found in established kwashiorkor must represent a late event. Turnover studies in recent years give us more insight. Picou and I have shown that in infants in the early stages of recovery from malnutrition the breakdown rate of plasma albumin is much less than after full recovery, and the half-life twice as long (Picou \& Waterlow, I962) (Table 3). This slowing of breakdown is still evident even after plasma albumin concentrations have returned nearly to the normal level. Hoffenberg, Saunders, Linder, Black \& Brock ( 1962 ) put adults on a low-protein diet for several weeks and found that there was no change in albumin concentration or total circulating albumin, but a significant increase in albumin half-life and a decrease in size of the extravascular pool. These changes occurred at a very early stage of depletion, after the loss of only 50-100 g of body N. This preferential reduction of the extravascular pool agrees with the experimental results of Yuile and co-workers (Yuile, Lucas, Neubecker, Cochrane \& Whipple, 1959). 
Table 3. Albumin metabolism in malnourished infants before and after treatment

$\begin{array}{lcc} & \text { Malnourished } & \text { Recovered } \\ \begin{array}{l}\text { Fractional turnover rate } \\ \quad \% \text { of intravascular albumin/day) }\end{array} & 8 \cdot 9 & 14 \cdot 5 \\ \begin{array}{l}\text { Absolute turnover rate } \\ \text { (mg/kg day) }\end{array} & 231 & 3 \text { I } 7 \\ \begin{array}{l}\text { Half-life (days) } \\ \text { I }\end{array} & 24.6 & \text { I3.I }\end{array}$

These findings agree entirely with the classical work of Whipple and his colleagues (Madden \& Whipple, I940; Whipple \& Madden, 1944) that albumin concentration and intravascular albumin mass are quantities that tend to be kept constant even in fairly advanced depletion. What is new is the indication of how this constancy is maintained: by a reduction in the rate of breakdown, and by contraction of the extravascular pool, which may in this sense be regarded as a reserve. We know nothing, however, of how these changes are brought about and regulated.

We have, therefore, two contrasting protein masses: on the one hand muscle, which in depletion bears the brunt of the loss and on refeeding is only slowly reconstituted; on the other hand, plasma albumin which is protected until the last stages and is rapidly restored the moment food is given. Although the pattern of protein depletion is shifting and complicated, it may be that simultaneous measurement of these two protein masses would give a broadly representative picture. Both measurements are fairly simple with existing techniques, although it will require some ingenuity to apply them on a large scale in the field.

\section{REFERENCES}

Addis, 'T., Poo, L. J. \& Lew, W. (1936). F. biol. Chem. Ir5, I17.

Arroyave, G. (1962). Paper read at Symposium on Mild-Moderate Forms of Protein-Calorie Malnutrition. Swedish Nutrition Foundation, Båstad, Sweden, 1962. To be published.

Arroyave, G. \& Wilson, D. (I96r). Amer. F, clin. Nutr. 9, I 70.

Bigwood, E. J. (1954). In Malnutrition in African Mothers, Infants and Young Children. Report of the Second Inter-African (C.C.T.A.) Conference on Nutrition, Gambia, 1952, p. 249. London: H.M. Stationery Office.

Bleiler, R. A. \& Schedl, H. P. (1962). F. Lab. clin. Med. 59, 945.

Darrow, D. C. \& Hellerstein, S. (1958). Physiol. Rev. 38, II4.

Dean, R. F. A. (1961). Fed. Proc. 20, 202.

Edozien, J. C. (1961). Pediatrics, Springfield, 27, 325.

Edozien, J. C. \& Phillips, E. J. (1961). Nature, Lond., 191, 47.

Folin, O. (1905a). Amer. F. Physiol. 13, 45.

Folin, O. (1905b). Amer. F. Physiol. 13, 66.

Hoffenberg, R., Saunders, S., Linder, G. C., Black, E. \& Brock, J. F. (1962). In Protein Metabolism: Infuence of Growth Hormone, Anabolic Steroids and Nutrition in Ilealth and Discase, p. 314. [F. Gross, editor.] Berlin: Springer-Verlag.

Kerpel-Fronius, E. \& Frank, K. (1949). Ann. Paediat. 173, 321.

Knox, W. E., Auerbach, V. H. \& Lin, E. C. C. (1956). Physiol. Rev. 36, I64.

Luyken, R. \& Luyken-Koning, F. W. M. (1960). Trop. geogr. Med. 12, 237.

McLean, A. E. M. (1962). Lancet, ii, 1294.

Madden, S. C. \& Whipple, G. H. (1940). Physiol. Rev. 20, 194.

Mendes, C. B. \& Waterlow, J. C. (1958). Brit. F. Nutr. 12, 74.

Miller, A. T. \& Blyth, C. S. (1952). F. appl. Physiol. 5, 73.

Montgomery, R. D. (1962). F. clin. Path. r5, 5 I r.

Phansalkar, S. V. \& Patwardhan, V. N. (1954). Indian Y. med. Res. 42, 363.

Picou, D. \& Waterlow, J. C. (1962). Clin. Sci. 22, 459.

Platt, B. S. (1954). In Malnutrition in African Mothers, Infants and Young Children: Report of the Second Inter-African (C.C.T.A.) Conference on Nutrition, Gambia, 1952, p. I53. London: H.M. Stationery Office. 
Platt, B. S. \& Heard, C. R. C. (1958). Proc. Nutr. Soc. 17, ii.

Standard, K. L., Wills, V. G. \& Waterlow, J. C. (1959). Amer. F. clin. Nutr. 7, 27 I.

Waterlow, J. C. (1948). Spec. Rep. Ser. med. Res. Coun., Lond., no. 263.

Waterlow, J. C. (1959). Fed. Proc. r8, 1143.

Waterlow, J. C. (1963). Amer. F. clin. Nutr. (In the Press.)

Waterlow, J. C., Cravioto, J. \& Stephen, J. M. L. (1960). Advanc. Prot. Chem. 15, 131.

Waterlow, J. C. \& Wills, V. G. (1960). Brit. F. Nutr. 14, 183.

Whipple, G. H. \& Madden, S. C. (I944). Medicine, 23, 2 I5.

Whitehead, R. G. \& Arnstein, H. R. V. (1961). Nature, Lond., 190, 1105.

Widdowson, E. M. \& McCance, R. A. (1956). Brit. F. Nutr. 10, 363 .

Yuile, C. L., Lucas, F. V., Neubecker, R. D., Cochrane, C. G. \& Whipple, G. H. (1959). F. exp. Med. rog, 165 .

\title{
Nutrition surveys-clinical signs and biochemical measurements
}

\author{
By G. R. Wadsworth, Sir Fohn Atkins Laboratories, Queen Elizabeth College, \\ University of London, London, W.8
}

\section{Introduction}

In assessing standards of health, especially in relation to nutrition, there is a danger of confusing primary conditions and secondary indices. For practical purposes the latter are usually emphasized, but it is well to remember that their relative importance may vary according to circumstances. The malarial parasite cannot flourish in erythrocytes containing sickle-cell haemoglobin (Allison, I957), so that the sicklecell trait is advantageous in areas where malaria is endemic and is there a feature of good, rather than poor, health. Growth is taken as an index of nutritional status, and until recently maximum rate of growth and maximum size have been regarded with favour. But in some communities rapid growth and large body size are now viewed with concern.

In defining optimal health, or optimal nutrition, it is necessary to look for absolute standards. We do not know the meaning of life and can therefore only suggest tentative criteria of normality. Perhaps survival is a main criterion: survival of the individual, the family and the human race. But survival alone does not seem enough and well-being might be added. It also seems desirable to include an idea of function, and this could be expressed as efficiency. Good nutrition would allow, and poor nutrition would partially or wholly inhibit, survival, well-being and efficiency.

Ill-health, whether through inadequate nutrition or some other cause, should ultimately be measured in terms of such criteria. But in nutrition surveys attention must be given to features of the body that can immediately be observed or measured. There is no sharp contrast between optimal health and various degrees of departure from it. In the diagram (Fig. I) I have indicated some of the features associated with different levels of nutritional status in the individual and in the community. Manifestations of malnutrition are frequently in the form of infective processes or simulate the effects of such processes. This is to say that it is usually impossible to separate syndromes entirely due to infection from those entirely due to malnutrition. In any event nutritional factors must be evaluated in order to plan programmes for improving standards of health. 